Bulgarian Academy of Sciences. Space Research and Technology Institute. Aerospace Research in Bulgaria. 30, 2018, Sofia

DOI: https://doi.org/10.3897/arb.v30.e11

\title{
SECONDARY POWER SYSTEMS FOR VIDEOMETRIC COMPLEX "FREGAT"
}

\author{
Pavlin Gramatikov, Roumen Nedkov, Doino Petkov \\ Space Research and Technology Institute - Bulgarian Academy of Sciences \\ e-mail:pgramatikov@space.bas.bg;rnedkov@space.bas.bg;dpetkov@stil.bas.bg
}

\begin{abstract}
The power supply for the video-spectrometric complex (VSC) "Fregat" is being considered. This secondary power supply systems have the following functions: Reception and switching of the voltages; Protection from overload and short circuit in the internal circuits and the exit circuits; Transformation of primary voltage in stabilized secondary voltages; Galvanically untethered secondary circuits by primary and Hull; Protection of the users from the electromagnetic noises; Provision of "Cold" and "Hot" reserve, etc. A set of technical documentation and test-measuring equipment for testing were created. Four sets of Secondary Power Systems for "Fregat" are designed and implemented for two flights to planet Mars.
\end{abstract}

\section{Introduction}

The VSC "Fregat" $[5,7]$ must perform two basic stages when photographing Phobos, Fig. 2: long-range photos and detailed photos with centimetre permission. VSC is managed from the Earth and then with the autonomous system itself solves the problems of convergence, hovering and flyby of $50 \mathrm{~m}$ from the surface of Phobos.

Eight blocks constructively shape VSC on the Fig. 1:

- Video Camera and Spectrometer (VCS), (1)

- Control System for VSC (CS VSC), (2)

- Video Storage Device for VSC (VSD VSC), (3)

- Secondary Power Supply System for VSC (SPSS VSC), (4)

- Electronics Block of the Video Storage Device (EB VSD VSC), (5)

- Block of the Tape Mechanism for VSD VSC (BBM VSD VSC), (6)

- Secondary Power Supply Unit for CS VSC (SPSU CS VSC), (7)

- Secondary Power Supply Unit for VSD VSC (SPSU VSD VSC), (8)

The functional elements of VSC "Fregat" are four blocks: (1), (2), (3) and (4). The two wide-range video camera channels at a distance of $50 \mathrm{~m}$ are authorized $50 \mathrm{~mm}$ and the spectral ranges of blue-green $(0.4 \div 0.6 \mu \mathrm{m})$ and of the nearby infrared radiation $(0.8 \div 1.1 \mu \mathrm{m})$. A narrow-angle channel shoots from a remote distance with an authorization of $20 \mathrm{~m}$ at a distance of $100 \mathrm{~km}$. In this channel is used the full range 
of matrix, which is $0.4 \div 1.1 \mu \mathrm{m}$. The spectrometer has an overall spectral clearance of $0.01 \div 0.02 \mu \mathrm{m}$. On flyby to Phobos (once every 7 days) from orbit, 3-5 series of 3 images must made, each with an interval of $75 \mathrm{~s}$. In a convergence stage with Phobos, a series of footage containing altitude information must made. With hovering and a movement of $50 \mathrm{~m}$ above the surface of Phobos must be obtained 180 frames with centimetric permission and 120 panoramic frames, which occupy a volume of 1.5 Gbit and are emitted for 30-60 sessions to the Earth. The planet Mars provides 120 frames of elliptical orbit and multiple photos of individual areas [7]. The block (2) provides automatic testing of VSC; applies the reservation logic according to the technical condition of the elements of the VSC and realizes the reconfiguration of the structure of the VSC in case of failure situations. The block (5) record and store video and spectrometric data and at appropriate times transmit it to the Earth with $200 \div 500$ times lower speed data to the telemetry channel [7]. Unit (6) performs the mechanical movement of the data media-magnetic tape.

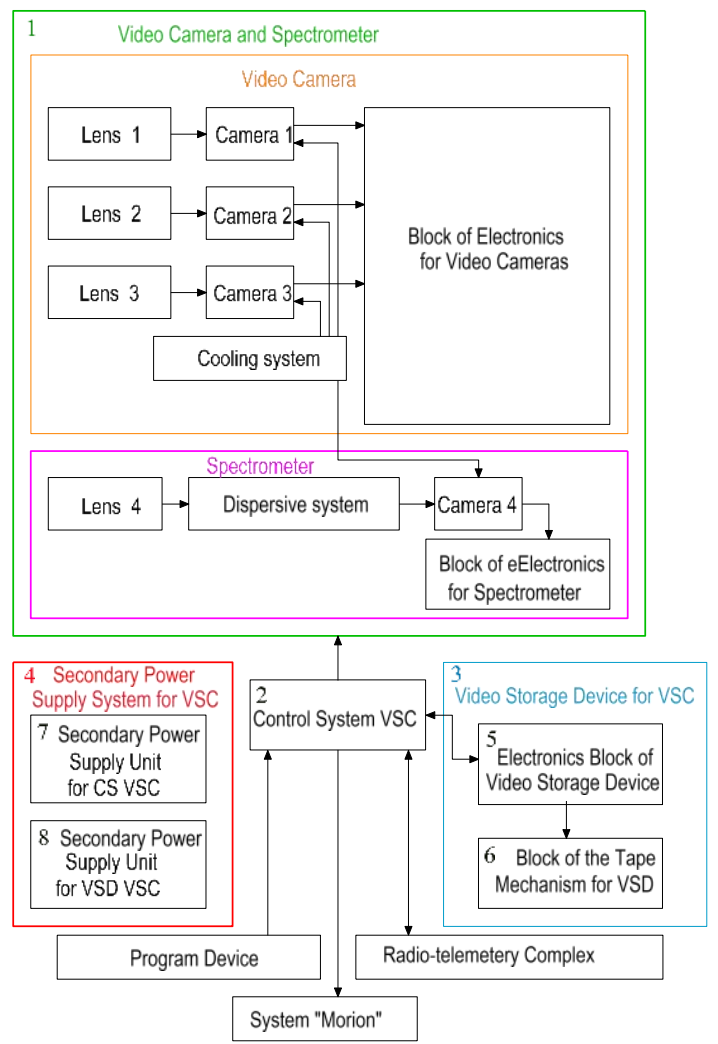

Fig. 1. Functional scheme of VSC "Fregat"

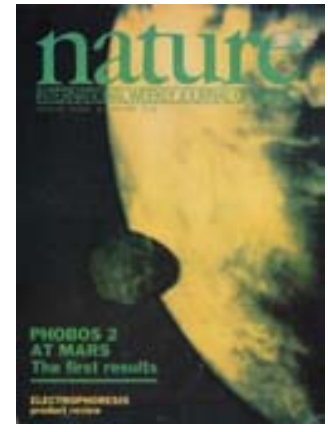

Fig. 2. Phobos in the background of Mars

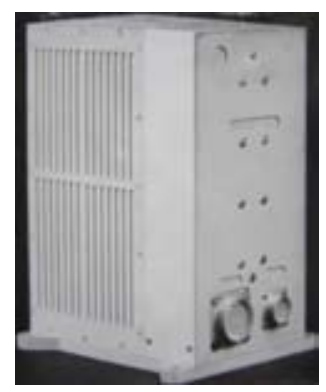

Fig. 3. Appearance of SPSU CS VSC and SPSU VSD VSC 


\section{Materials and methods}

\subsection{Secondary Power Supply Unit for CS VSC}

According to the technical specifications [1], the output voltages of SPSU CS VSC should be in the following ranges: $+5 \mathrm{~V}_{\mathrm{VSK}}+/-0.25 \mathrm{~V} ;+18 \mathrm{~V}_{\mathrm{VSK}}+$ $3 /-1.5 \mathrm{~V} ;-18 \mathrm{~V}_{\mathrm{VSK}} ;+3 /-1.5 \mathrm{~V}$ and $+27 \mathrm{~V}_{\mathrm{VSK}}+/-4 \mathrm{~V}$. The stability of the output voltages of SPSU CS VSC must be according to the Table 1, where the maximum permissible $\mathrm{K}_{\text {stab }}$ values are shown, under specified conditions.

Table. 1. Parameters of SPSU CS VSC

\begin{tabular}{|c|c|c|c|c|c|}
\hline \multicolumn{2}{|c|}{ Conditions of measurement of $\mathrm{K}_{\text {stab }}$} & \multicolumn{4}{|c|}{$\mathrm{K}_{\text {stab }}$} \\
\hline Change of BN & $\begin{array}{c}\text { Change of output } \\
\text { current }\end{array}$ & $+5 \mathrm{~V}_{\text {VSK }}$ & $+18 \mathrm{~V}_{\text {VSK }}$ & $-18 \mathrm{~V}_{\text {VSK }}$ & $+27 \mathrm{~V}_{\text {VSK }}$ \\
\hline $24 \div 30 \mathrm{~V}$ & $100 \%$ & $0.5 \%$ & $3 \%$ & $0.5 \%$ & $0.5 \%$ \\
\hline $27 \mathrm{~V}$ & $20 \div 100 \%$ & $5 \%$ & $15 \%$ & $5 \%$ & $5 \%$ \\
\hline $24 \div 30 \mathrm{~V}$ & $20 \div 100 \%$ & $6 \%$ & $20 \%$ & $8 \%$ & $8 \%$ \\
\hline
\end{tabular}

The overall appearance of SPSU CS VSC is given in Fig. 3 [3]. The front panel has dimensions $202 \times 100 \mathrm{~mm}$, and the width of the shell is $140 \mathrm{~mm}$. The time of establishment of the nominal values of the output voltages of SPSU CS VSC at start should be up to $0.1 \mathrm{~s}$. Constructive SPSU CS VSC is executed by two identical modules (SPSU CS1 VSC and SPSU CS2 VSC) and one common Relay Board (RB), Fig. 4. In case of failure of the module SPSU CS1 VSC or SPSU CS2 VSC, it must be disconnected from the $\mathrm{BN}$ for a time not exceeding $0.05 \mathrm{~s}$ by fuse. In the laboratory tests according to the space methodology for the EMC (created by SPSU CS VSC) unacceptable meanings of noises with high frequencies were measured. This requires the installation of an additional filter FEMC1, Fig. 4.

Relay board (RB) performs the following functions:

- Inclusion of SPSU CS1 VSC or SPSU CS2 VSC;

- Simultaneous inclusion of SPSU CS1 VSC and SPSU CS2 VSC;

- Simultaneous exclusion of SPSU CS1 VSC and SPSU CS2 VSC;

- Telemetry data for operating temperatures; command for switching of SPSU CS VSC and presence of $+5 \mathrm{~V}_{\text {VSK }}$.

Constructively SPSU CS1 VSC is in a separate box and consists of four PCB:

- CSF1 Unit serves three functions: limit the starting current by circuit of a smooth start CSS; filtration of the internal and external noises by FEMS2 and voltage stabilization (VS1) for voltage $+12 \mathrm{~V}_{\mathrm{bs}}$.

- Controller1 Unit - performs the management functions of SPSU CS1 VSC; 
- PTR1 Unit - realize the functions for: power amplifier (PA); transformer $(\mathrm{Tr})$; rectifiers Rt $\div$ Rt4 and voltage stabilization (VS2) for voltage $+27 \mathrm{~V}_{\text {vsk}}$;

- FB1 Unit - board of negative voltage feedback.

Controller1 unit has the following functions: generates impulse voltage $\mathrm{U}_{\mathrm{q} 1}$ and $\mathrm{U}_{\mathrm{q} 2}$ for PTR1; monitors and limits the current of the PTR1 by the signal $\mathrm{I}_{\mathrm{FB} 1}$ and ensures smooth charging of the capacitors in PTR1. He also monitors the tension of the BN and decides to exclude SPSU CS1 VSC when BN is less than $20 \mathrm{~V}$ or above $34 \mathrm{~V}$.

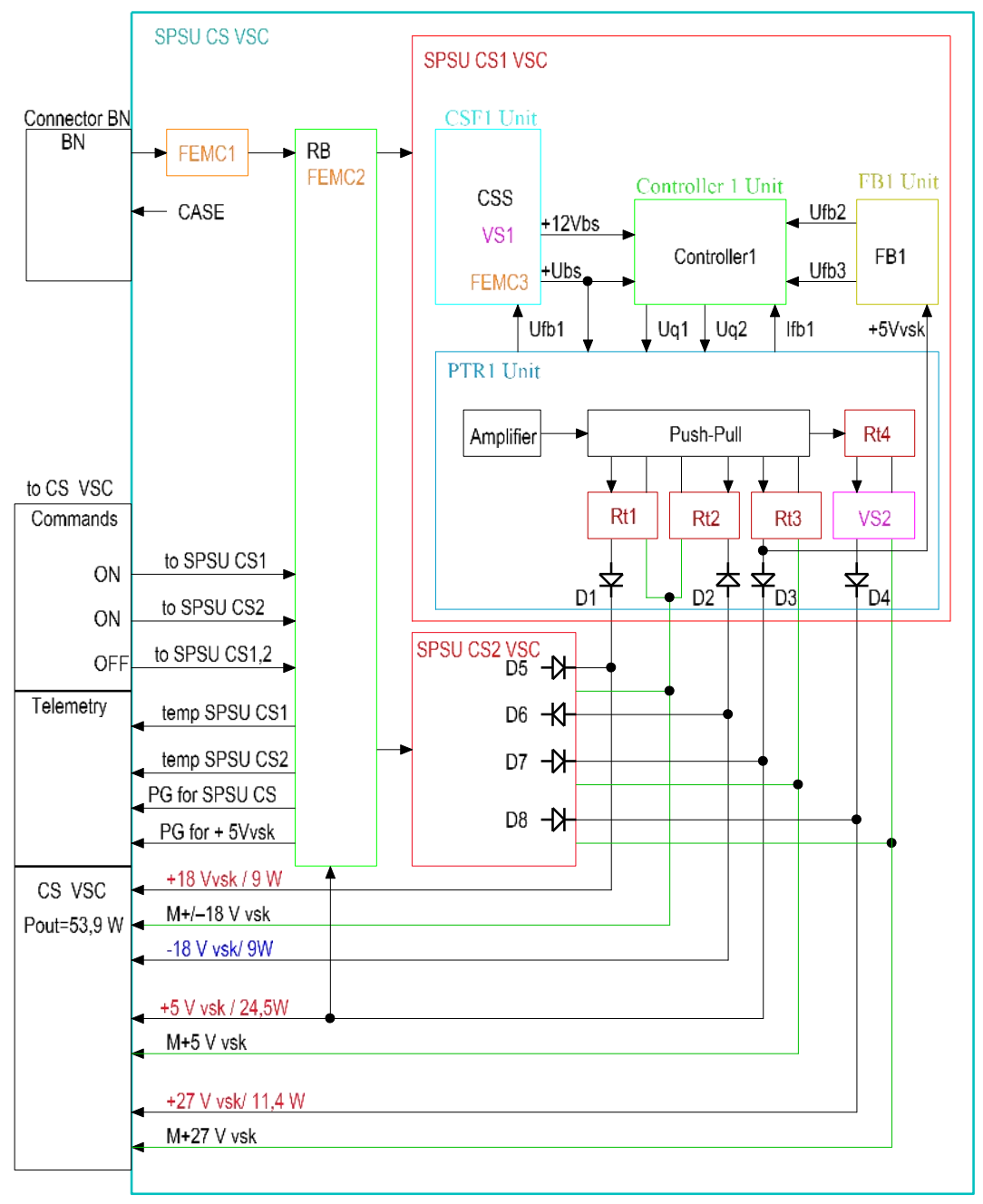

Fig. 4. Functional scheme of SPSU CS VSC 
The PCB FB1 monitors and stabilizes by $\mathrm{U}_{\mathrm{fb} 2}$ voltage $+5 \mathrm{~V}_{\mathrm{VSK}}$ for powering the digital part of CS VSK. One of the nodes of the FB1 traces for short surges of $+5 \mathrm{~V}_{\mathrm{VSK}}$ and submits command $\mathrm{U}_{\mathrm{fb} 3}$ for rapid reduction of the output voltages of the SPSU CS VSC. The primary requirement for the design of space research equipment is the creation and use of Control and Measurement Equipment (CME). Through the CME the working capacity of the scientific devices is checked, the acceptance and executing of the commands are measured, the parameters of SPS in the Ground Based Autonomous and Complex Tests [24]. For the SPSU CS1 VSC and SPSU CS2 VSC, the CME is made according to [4] and is used for measurements according to [2-4]. At full load and at three different voltage values of BN with KIA, the starting currents of SPSU CS1 VSC LK-1 and SPSU CS1 VSC LK-2 are measured, Fig. 5 and Fig. 6 . From BN at time $\Delta \mathrm{t}=0 \div 50 \mathrm{~ms}$ becomes charge of the primary capacitors. The secondary capacitors are charged in the interval $\Delta \mathrm{t}=100 \div 350 \mathrm{~ms}$. There is a large identity of the parameters of the two channels of (SU1 and SU2) and the starting current does not "exceed 5 times the nominal time less than $0.2 \mathrm{~s}$ ", according to the electrical requirements $[2,3]$. The UFB1 voltage serves to saturate the transistor in CSF1, which reduces thermal losses. To the $+27 \mathrm{~V}_{\text {VSK }}$ connect to about $0.2 \mathrm{~s}$ the windings of the relays, switching the primary spare boards of CS VSC, i.e. the cargo in this chain is highly dynamic and requires the use of VS2. In order to make the "hot" mode of SPSU CS VSC are used diodes D1, D2, D3, D4,

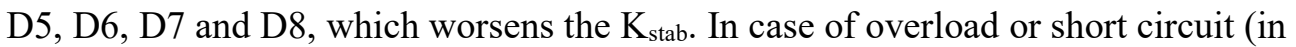
PTR1 or CS VSC) the voltage proportional to the current Ifb1 is used to limit the current SPS CS1 VSC consumption.

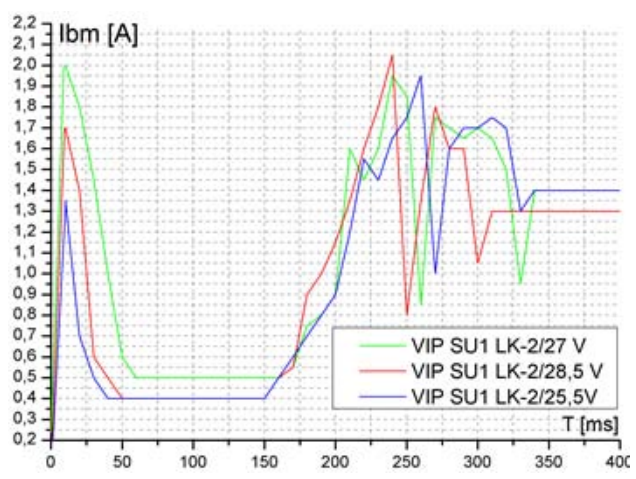

Fig. 5. Starting current of SPS CS1 VSK LK-2

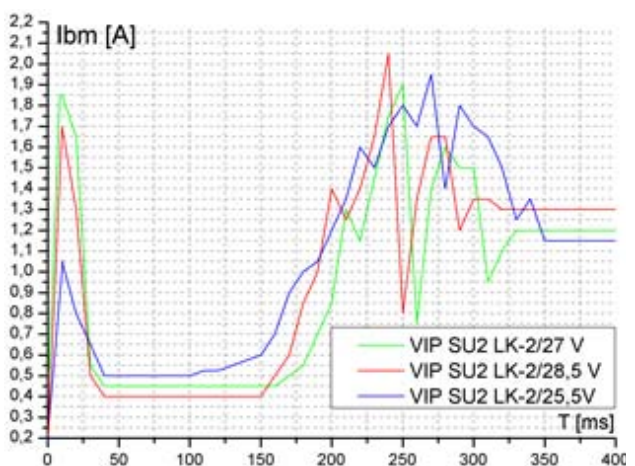

Fig. 6. Starting current of SPS CS2 VSK LK-2 


\subsection{Secondary Power Supply Unit for VSD VSC}

In Fig. 7 is given the functional scheme of SPSU VSD VSC [4]. The loads of SPS VSD VSK in different modes are given in Table 2. In "Standby" mode $+5 \mathrm{~V}_{\mathrm{a}}$ only works and SPS consume from BN only $1.125 \mathrm{~W}$.

Table. 2. Loads of the SPS VSD VSK in different modes

\begin{tabular}{|l|l|c|c|c|c|c|}
\hline \multicolumn{1}{|c|}{ Mode } & Dimensions & +5 Va VSD & +12 V VSD & -12 V VSD & +5 Vd VSD & Pout \\
\hline Record & {$[\mathrm{W}]$} & 0.825 & 2.52 & 7.92 & 16.75 & 28.015 \\
\hline Play & {$[\mathrm{W}]$} & 0.825 & 3.24 & 10.80 & 12.50 & 27.365 \\
\hline Delete & {$[\mathrm{W}]$} & 0.825 & 2.40 & 8.16 & 10.00 & 21.385 \\
\hline Rewind & {$[\mathrm{W}]$} & 0.825 & 2.40 & 7.92 & 16.75 & 27.895 \\
\hline
\end{tabular}

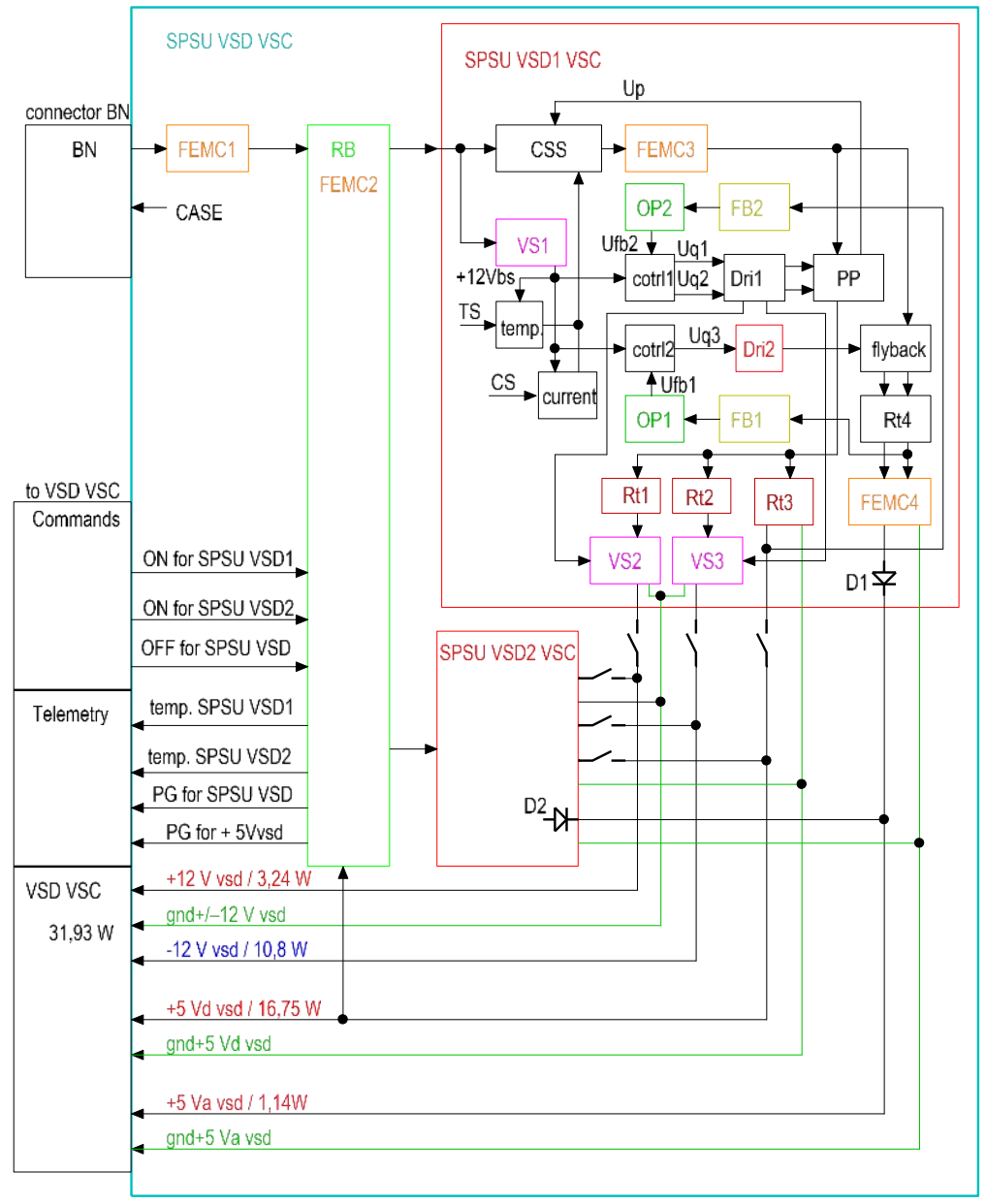

Fig. 7. Functional scheme of SPSU VSD VSC 
The appearance and dimensions of SPSU VSD VSC are similar to SPSU CS VSC. The difference is in the functional and principle scheme: there is a "hot" reserve only for Standby mode $+5 \mathrm{~V}_{\mathrm{VSD}}$, and the contacts of the relays are used for the "cool" reserve of the remaining voltages. The mode off duty cycle is carried out with a Flyback converter (UDR, OPTV, S, ovn1, FEMS4, Ovn1, Or1, D1) and the main mode-with the other blocks. In comparison with SPS CS VSK in SPS VSD VSK are added TC and ZKSP with functions of temperature control and protection against short circuit.

\subsection{Parallel Stabilizer for VSD VSC}

When was first connection on the technological specimen of SPSU VSD VSC to the technological model of VSD VSC, an unacceptable noise of the video data is obtained. It is found that the low-frequency engine current of the tape recorder induces a surge in voltage $-12 \mathrm{~V}_{\mathrm{VSD}}$, where are connected sensitive amplifiers of the video signals. The problem is solved by a copyright solution by attaching a current stabilizer in the chain of $-12 \mathrm{~V}_{\mathrm{VSD}}$ [6]. Scheme of parallel stabilizer of current PSVSD-VSC is given on Fig. 8. The signal "ITM" enabled VSD VSC in the mode "recording" and "playback" (Table 2) characterized by unacceptable noise of the video data. For saving electricity in the remaining modes, PS-VSD-VSC is in standby mode.

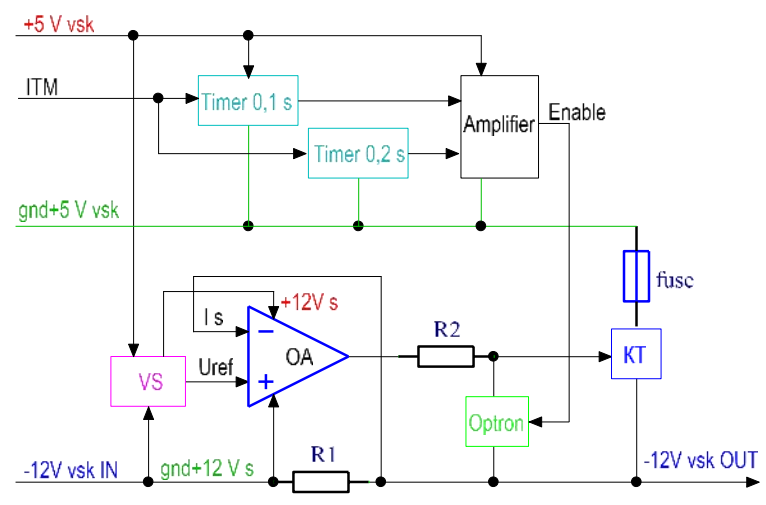

Fig. 8. Functional scheme of PS-VSD-VSC, Project „PHOBOS“

\section{Results}

Phobos images are captured at a distance of $320 \div 440 \mathrm{~km}$. There are 5 series pictures of Phobos from distance $184 \div 223 \mathrm{~km}$. The total number of photos of Phobos are 37, of which 8 in the background of Mars [24]. The Scientific program 
52 days (flight 83 days) is performed by "Phobos-1" mission and 200 days (flight 255 days) from "Phobos-2" mission.

\section{Discussion}

VSC provides the special task of the spacecraft - the main navigational task of space mission during flight to planet Mars, in orbital flight and convergence to Phobos. When flying to Mars and conducting the navigation sessions for the "Phobos-2" becoms one instability of the operation of the TV channels 1 and 2. After reconfiguration of VSK with switching the additional SPS CS2 VSC and automatically transitioning to a backup subordinate processor, the reliable operation of these channels is restored.

\section{References}

1.Основные технические характеристики автоматической универсальной орбитальной станции АУОС и техническе требования для устанавливаемой на ней научной аппаратуре, АН СССР, ИНТЕРКОСМОС, 1982.

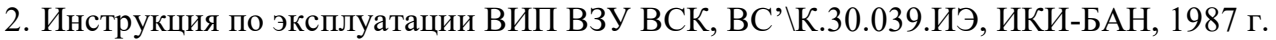

3. Вторичный источник питания системы управления, проект „Фобос“, Техническое описание ВИП СУ ВСК, ВСК.30.038.ТО, ВИП СУ ВСК ЛК-1, ИКИ-БАН, 1987.

4.Частный протокол приемо-сдаточных (ПСИ) и конструкторо-доводочных (КДИ) испытаний, ВИП ВЗУ ВСК ЛК-2, ВИП ВЗУ ВСК ЛК-3, Недков Р., П. Граматиков, Р. Тодоров, В. Янков, М. Иванов, И. Иванова, В. Шаламанов, Техническое и технологическое обеспечение медико-биологической программы проекта „Шипка“, Экспрес отчет БАН, София, 1988.

5. Avanesov, G. A., B. I. Bonev, et al. Television observations of Phobos, Nature, 1989, 341, $6243,585-87$.

6. Граматиков, П., Метод за подтискане на нискочестотни токови пулсации в захранването на цифровото видеозапомнящо устройство на видеоспектрометричния комплекс „Фрегат“ от проекта „Фобос“, 2-ра национална конференция „Аерокосмос и екология“, Шумен, 19-20 април 1990 г.

7. Аванесов, Г. А., и др., Телевизионные исследования Фобоса. К.Н.-М.: Наука, 1994. 168 с. ISBN 5-02-000298-4.

8. Граматиков, П., Р. Недков, Д. Петков, Вторична електрозахранваща система на видео запомнящо устройство от видео спектрометричен комплекс, In: $6^{\text {th }}$ International scientific and technical conference, "Engineering, technologies, education, security", 2018, Veliko Tarnovo, 191-93. 


\title{
ВТОРИЧНИ ЕЛЕКТРОЗАХРАНВАЩИ СИСТЕМИ ЗА ВИДЕОСПЕКТРОМЕТРИЧЕН КОМПЛЕКС „ФРЕГАТ“
}

\author{
П. Граматиков, Р. Недков, Д. Петков
}

\begin{abstract}
Резюме
В настоящата статия се разглежда системата за вторично електрозахранване на Видео-спектрометричен комплекс "Фрегат" и параметри на първичното захранване (ПЗ). Тя се състои от две вторични електрозахранващи системи (BEC) и един паралелен стабилизатор, които имат следните функции: приемане и превключване на ПЗ; защита на ПЗ от претоварване и късо съединение във вътрешните вериги и изходните вериги на BEC; трансформация на първичното напрежение в стабилизирани вторични напрежения (галванично развързани от ПЗ и корпуса); защита на ползвателите на ВЕС от шумовете на ПЗ; ограничаване на нивото на шума, създаден от ВЕС в ПЗ; осигуряване на "студен" и "горещ" резерв и др. Предложеното решение за ВЕС доказва себе си при нещатна полетна ситуация. Създадени са комплект техническа документация и контролно-измервателна апаратура за изпитания. Проектирани, разработени и реализирани са по четири броя от ВЕС за "Фрегат" за два полета до планетата Марс. Спътникът Фобос на планетата Марс е заснет от разстояние $320 \div 440 \mathrm{~km}$. Направени са 5 серии снимки на Фобос от разстояние $184 \div 223 \mathrm{~km}$. Общият брой на снимките на Фобос са 37 , от които 8 на фона на планетата Марс.
\end{abstract}

